\title{
REMOVAL OF POTENTIALLY TOXIC ELEMENTS IN DOMESTIC WASTEWATER TREATMENT STATIONS BY CONSTRUCTED WETLANDS
}

\author{
Schirmer, W.N¹.; Kozak, C².; Gomes ${ }^{3}$, S.; Santos ${ }^{3}$, L.Mㄹ.; Fonseca, A.F ${ }^{4}$. \\ 1 Universidade Estadual do Centro-oeste (UNICENTRO); \\ 2 Universidade Federal do Paraná (UFPR); \\ 3 Universidade Tecnológica Federal do Paraná (UTFPR), \\ 4 Universidade Estadual de Ponta Grossa (UEPG); \\ *Corresponding author: wanasch@hotmail.com
}

\begin{abstract}
Schirmer, W.N.; Kozak, C.; Gomes, S.; Santos, L.M..; Fonseca, A.F.. 2014. Removal of Potentially Toxic Element in Domestic Wasterwater Treatment Stations by Constructed Wetlands. Braz. J. Aquat. Sci. Technol. 19(1):7-11. eISSN 1983-9057. DOI: 10.14210/bjast.v19n1.p7-11 Lack of sewage treatment is amongst the main sanitation problems of Brazil, mainly in low income rural communities. Seeking alternative and low cost technologies to treat such effluents is mandatory. This study aimed to verify the efficacy of a sewage treatment system by root zone stations (constructed wetlands) to remove potentially toxic elements (Cu and Zn) in two wastewater treatment stations (WWTS) (school and single family residence) of small communities in the city of Irati (PR). Three campaigns were carried out between May and September 2011, with two samples each (inlet and outlet), all in replicate, and quantified through atomic absorption spectrometry with flame atomization (AAS-flame). The presence of $\mathrm{NH}_{3}$ in the effluent favored the reduction of $\mathrm{pH}$ values, which remained within the neutrality and alkalinity range (from 8.0 to 9.1 for the school effluent and from 6.9 to 7.8 for the single family residence). For this $\mathrm{pH}$ range, it was possible to obtain $\mathrm{Cu}(25 \%$ to $75 \%)$ and $\mathrm{Zn}(0$ to $100 \%)$ precipitation. In general, the constructed wetlands systems were efficient to remove $\mathrm{Cu}$ and $\mathrm{Zn}$ (between $25 \%$ to $75 \%$ regarding $\mathrm{Cu}$; and between $67 \%$ to $100 \%$ regarding $\mathrm{Zn}$ ), revealing advantages of its use in small communities.
\end{abstract}

Keywords: constructed wetlands, domestic wastewater, potentially toxic elements, small communities.

INTRODUCTION

Conventional sewage treatment systems to small communities have become, sometimes, economically unviable due to high costs of construction and operation (Verhoeven \& Meuleman, 1999; Al-Omari \& Fayyad, 2003; Solano et al., 2004). Sousa et al.(2004) report the need to develop economically technologies to treat wastewater. In this sense, wetlands are a highly efficient alternative.

Wetland systems are advantageous over conventional systems, as (i) they present low construction, operation and maintenance costs (Neralla et al., 2000; Solano et al., 2004); (ii) produce less amounts of sludge (Ran et al., 2004); (iii) can be implemented at the place where the sewage is generated (Neralla et al., 2000) and (iv) can be operated by non-specialized staff (Neralla et al., 2000; Solano et al., 2004).

Constructed wetlands are classified in the literature according to the flow - either surface or subsurface (USEPA, 2000) or according to some authors, in vertical or horizontal flow (Santiago et al., 2005). According to Shutes (2001), the subsurface flow is most efficient than surface flow, as the effluent level remains below the soil surface (Schirmer \& Oliveira, 2010).

In order to obtain higher treatment efficacy, raw sewage needs to pass firstly through a septic tank (primary treatment) to remove coarse solid, and then through the wetland system (secondary treatment), which promotes natural processes (Van Kaick, 2002;
Schirmer \& Oliveira, 2010). The treatment systems by wetlands are slow filters which present beds (support) filled up with high hydraulic conductivity materials (gravel and sand), on which the plants grow. Figure 1 presents a scheme of a treatment system by constructed wetlands.

According to Hill \& Payton (2000) and USEPA (2000), the mechanisms in sewage treatment by wetlands comprise physical, chemical and biological processes, in which plant, substrate and biofilms (microbial aggregates that fix to the support material) act together. The combination of these mechanisms results in the removal of several pollutants present in the sewage, such as organic matter, nutrients, suspended solids and coliforms (Ran et al., 2004). Besides these pollutants, heavy metals can also be removed through this system (Dunbabin \& Bowmer, 1992). Among the heavy metal removal processes are filtration and sedimentation of suspended particles, adsorption and precipitation by biogeochemical processes (Stottmeister et al., 2003).

Several authors have reported the wetlands efficacy in removal of heavy metals (Marques et al., 1997; Scholes et al. 1998; Weis e Weis, 2004; Maine et al. 2007; Galletti et al. 2010). The present work focus on evaluating the removal of potentially toxic elements ( $\mathrm{Cu}$ and $\mathrm{Zn}$ ) in constructed wetlands of small communities relating the removal efficacy with the $\mathrm{pH}$ values. Such a study is justified by the toxicity of these compounds. 


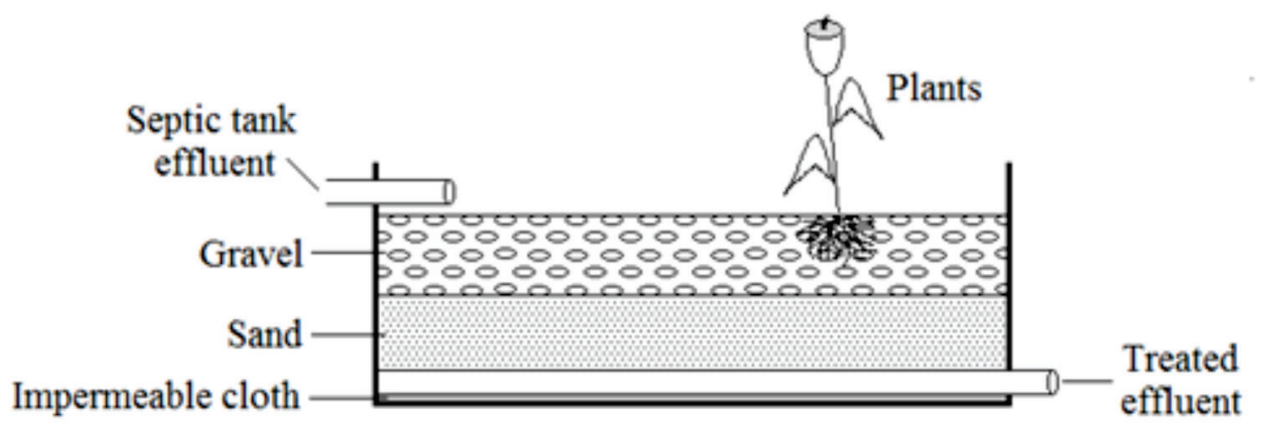

Source: Schirmer et al. (2012)

FIGURE 1 - Scheme of an effluent treatment system by constructed wetlands.

\section{MATERIAL AND METHODS}

The WWTS by root zone (constructed wetlands) under study were located in small communities in city of Irati - PR and serve, respectively, a school (with approximately 230 students) and a single family residence (with five inhabitants).

These systems comprised three zones. The first one was the Calla Lily (Zantedeschia aethiopica, [(L.) Spreng.]) root zone, which was selected due to its efficacy in removing chemical, physical and biological parameters from the wastewater (Schirmer et al., 2009; Schirmer \& Oliveira, 2010) and because it is easily adaptable to the region where the study was carried out - temperate climate with average temperatures of $18^{\circ} \mathrm{C}$ in the winter and $22^{\circ} \mathrm{C}$ in the summer (IAPAR, 2013). The second zone, or first filter on which the Calla Lily is planted, was formed by a $50-\mathrm{cm}$ deep layer of gravel number two. Finally, the third zone, or second filter, was a 40-cm layer of sand with medium to coarse granulometry. The gravel and sand layers were placed in an area which was made waterproof by the use of plastic canvas (triple layer of $0.8 \mathrm{~mm}$ ) whose aim was avoid the contamination of soil and groundwater around the system, as well as to avoid the effluent contamination with external agents. The raw sewage coming from the septic tank gets to the wetland and the treated effluent, in this case, is captured by pipes that are located under the sand layer.

Three campaigns were carried out in the period from May to September 2011, each one with two sampling points, one upstream (after the septic tank) and the other downstream of each wetland system, all in duplicate. Collection was carried out according to Standards Methods for the Examination of Water and Wastewater (APHA, 1998). After collection, each sample was divided into two subsamples ("a" and "b"). Subsamples (a) were used in $\mathrm{pH}$ and ammonia $(\mathrm{NH}\urcorner 3\urcorner)$ concentration analyses through potentiometric $(4500 \mathrm{H}+\mathrm{B})$ and distillation/nitration $\left(4500-\mathrm{NH}_{3} \mathrm{C}\right)$ methods, also according to APHA (1998). Subsamples (b) were acidified in diluted hydrochloric acid $(\mathrm{pH}<$ 2.0), stored in high density polyethylene (HDPE) bottles and stored at low temperature $\left(4^{\circ} \mathrm{C}\right)$ until the digestion procedure using perchloric acid; in the sequence, $\mathrm{Cu}$ and $\mathrm{Zn}$ were quantified through atomic absorption spectrometry with flame atomization (AAS-flame, model Varian AA240 FS, precision: $1 \%$ ).

\section{RESULTS AND DISCUSSION}

In WWTS, the organic nitrogen is biologically transformed into ammonia through the ammonification (IWA, 2000) and, in acid medium, it prevails as cation ammonia $\left(\mathrm{NH}_{4}^{+}\right)$(Valentim, 2003). When the $\mathrm{pH}$ is above seven, there is reduction in the $\mathrm{NH}_{4}^{+}$species and an increase in the $\mathrm{NH}_{3}$ - species, ammonia gas, which diffuses at the site (Chapra, 1997). For values close to neutrality, the amount of $\mathrm{NH}_{4}{ }^{+}$is higher, establishing some balance with the ammonia molecular specie when the $\mathrm{pH}$ is around 9.25 (WEF, 1995).

Table 1 shows the sewage $\mathrm{NH}_{3}$ and $\mathrm{pH}$ values (average of duplicates) at the upstream wetland (septic tank output) and the downstream wetland in both school and single family residence WWTS evaluated during the three sampling campaigns.

All $\mathrm{pH}$ values were slightly alkaline (average of 8.5 for the school effluent and 7.4 for the single family residence effluent) favoring the predominance of $\mathrm{NH}_{4}^{+}$ in the effluent; this ion can be, through the nitrification process, oxidized to nitrated (Chapra,1997). This process results in release of protons and a decrease in $\mathrm{pH}$ values (Valentim, 2003). Therefore, reductions in $\mathrm{pH}$ 
values between the input and output of both WWTS might be due to nitrification. However, the $\mathrm{NH}_{3}$ removal rate (average of $48 \%$ for the school effluent and $72 \%$ for the single family residence effluent) did not attend, in any campaign, the requirements of the current law for the effluent release patterns - the maximum value of 20 mg.L-1 for the ammonium nitrogen total (CONAMA, 2011); so, at least for the evaluated conditions, system was insufficient for ammonia removal.

$\mathrm{pH}$ indicates conditioning and availability of metals in the soil, acting on the balance of several chemical species, mainly regarding solubility. Thus, metals, including $\mathrm{Cu}$ and $\mathrm{Zn}$, have their availability reduced in a aqueous medium with the $\mathrm{pH}$ increase, as they precipitate in the form of hydroxides and carbonates (Mota \& Von Sperling, 2009), forming compounds which are insoluble in water.

Table 2 shows $\mathrm{Zn}$ and $\mathrm{Cu}$ values (average of duplicates) at the upstream wetland (septic tank output) and the downstream wetland in both school and single family residence WWTS evaluated during the three sampling campaigns. Zinc tends to precipitate when the medium presents $\mathrm{pH}$ values close to eight; the copper has high adsorption capacity in the filter bed in environments with $\mathrm{pH}$ around five and six (Fia, 2009). For $\mathrm{pH}$ values between seven and nine, the $\mathrm{Cu}$ precipitation might occur in the form of hydroxides (Jordão et al., 2000). According to Table 1, pH values of school and single family residence effluents, in all campaigns, were around neutrality and alkalinity (considering the WWTS input and output values), contributing to the efficacy of the removal of such metals. The percentage of removal presented in the first zinc campaign $(0 \%)$, pointing out that removal was practically no observed in this case for this point (single family residence, as can be seen in Table 2), what indicates the need to realize other campaigns/samplings.
Suitable $\mathrm{pH}$ conditions (in the slightly alkaline range) made the metals precipitation possible, as they were retained in the physical system of the filter. Once precipitated, the $\mathrm{Cu}$ and $\mathrm{Zn}$ elements suffer complexation (Faquin, 2005) (interaction between these metals and the organic matter present in the environment) and become available to the plant. According to Daigo (1997), plants have the capability of accumulating $\mathrm{Zn}$ more quickly than $\mathrm{Cu}$, which might have contributed for the greater removal of $\mathrm{Zn}$ in relation to $\mathrm{Cu}$, observed in this study.

In a study carried out by Bertholdo (1999), two wetland stations were analyzed which received effluent from an upflow anaerobic sludge blanket (UASB) in real scale in a WWTS, planted with the macrophytes Typha subulata and Zizaniopsis bonariensis; when there was reduction in the $\mathrm{pH}$ to a value of $5.6, \mathrm{Zn}$ removal efficacies were around $43.6 \%$ and $28.8 \%$ for both species. Similarly, in the study carried out by Garcia (2003), Cu removal through constructed wetlands to effluent of gold factories, the $\mathrm{pH}$ remained around 8 and 8.5 reaching $97.99 \%$ efficacy; the same author stated that "the metallic complex formed by Cu will precipitate usually as insoluble hydroxide or carbonate compound". In another study, Anjos (2003), evaluating a wetland that received toxic waste from a slag landfill, obtained the removal of $100 \%$ zinc and copper in slightly alkaline $\mathrm{pH}$ conditions.

\section{CONCLUSIONS}

The constructed wetlands stations evaluated showed to be efficient to remove potentially toxic elements (between $25 \%$ to $75 \%$ for $\mathrm{Cu}$; and between $0 \%$ to $100 \%$ for $\mathrm{Zn}$ ), since the environment conditions (such as $\mathrm{pH}$ around seven and nine) are favorable. The values of removal found indicates the need to realize other campaigns/samplings.

TABLE 1 - Ammonia and pH values for the WWTS input and ouput for the school and single family residence, as well as their removal percentage.

\begin{tabular}{ccccccc}
\hline \hline \multirow{2}{*}{$\begin{array}{c}\mathbf{N H}_{3} \\
\left(\mathbf{m g ~ L}^{-1}\right)\end{array}$} & $\begin{array}{c}\text { WWTS } \\
\text { Input }\end{array}$ & $\begin{array}{c}\text { WWTS } \\
\text { Output }\end{array}$ & $\begin{array}{c}\text { Removal } \\
(\%)\end{array}$ & $\begin{array}{c}\text { WWTS } \\
\text { Input }\end{array}$ & $\begin{array}{c}\text { WWTS } \\
\text { Output }\end{array}$ & $\begin{array}{c}\text { Removal } \\
(\%)\end{array}$ \\
\hline Campaign 1 & 172.00 & 26.00 & $85 \%$ & 101.00 & 32.00 & $68 \%$ \\
\hline Campaign 2 & 225.40 & 149.20 & $34 \%$ & 149.70 & 45.60 & $70 \%$ \\
\hline Campaign 3 & 244.40 & 181.40 & $26 \%$ & 116.70 & 24.80 & $79 \%$ \\
\hline \multicolumn{5}{c}{ pH } & \multicolumn{5}{c}{ School } \\
\cline { 2 - 7 } & WWTS Input & WWTS Output & WWTS Input & WWTS Output \\
\hline Campaign 1 & 9.1 & 8.0 & 7.8 & 7.1 \\
\hline Campaign 2 & 9.0 & 8.1 & 7.8 & 7.1 \\
\hline Campaign 3 & 8.7 & 8.2 & 7.6 & 6.9 \\
\hline \hline
\end{tabular}


TABLE 2 - Concentrations of Zn and Cu from the WWTS input and output in the school and single family residence.

\begin{tabular}{|c|c|c|c|c|c|c|}
\hline \multirow{2}{*}{$\begin{array}{c}\text { Zinc } \\
\left(\mathrm{mg} \mathrm{L}^{-1}\right)\end{array}$} & \multicolumn{3}{|c|}{ School } & \multicolumn{3}{|c|}{ Single family residence } \\
\hline & $\begin{array}{l}\text { WWTS } \\
\text { Input }\end{array}$ & $\begin{array}{l}\text { WWTS } \\
\text { Output }\end{array}$ & $\begin{array}{c}\text { Removal } \\
(\%)\end{array}$ & $\begin{array}{c}\text { WWTS } \\
\text { Input }\end{array}$ & $\begin{array}{l}\text { WWTS } \\
\text { Output }\end{array}$ & $\begin{array}{c}\text { Removal } \\
(\%)\end{array}$ \\
\hline Campaign 1 & 0.38 & 0.08 & 79 & 0.06 & 0.06 & 0 \\
\hline Campaign 2 & 0.10 & 0.02 & 80 & 0.08 & 0.00 & 100 \\
\hline Campaign 3 & 0.26 & 0.00 & 100 & 0.12 & 0.04 & 67 \\
\hline \multirow{2}{*}{$\begin{array}{l}\text { Copper } \\
\left(\mathrm{mg} \mathrm{L}^{-1}\right)\end{array}$} & \multicolumn{3}{|c|}{ School } & \multicolumn{3}{|c|}{ Single family residence } \\
\hline & $\begin{array}{c}\text { WWTS } \\
\text { Input }\end{array}$ & $\begin{array}{l}\text { WWTS } \\
\text { Output }\end{array}$ & $\begin{array}{c}\text { Removal } \\
(\%)\end{array}$ & $\begin{array}{c}\text { WWTS } \\
\text { Input }\end{array}$ & $\begin{array}{l}\text { WWTS } \\
\text { Output }\end{array}$ & $\begin{array}{c}\text { Removal } \\
(\%)\end{array}$ \\
\hline Campaign 1 & 0.12 & 0.08 & 33 & 0.06 & 0.04 & 33 \\
\hline Campaign 2 & 0.08 & 0.06 & 25 & 0.06 & 0.04 & 33 \\
\hline Campaign 3 & 0.16 & 0.04 & 75 & 0.08 & 0.04 & 50 \\
\hline
\end{tabular}

The wetland physical medium (gravel and sand filter), allied to the biological system (macrophyte), was shown to be the major responsible for good metal removal rates. In addition, the presence of plants may have contributed to a greater removal of $\mathrm{Zn}$ in relation to $\mathrm{Cu}$.

\section{ACKNOWLEDGEMENTS}

Authors are thankful to Fundação Araucária de Apoio ao Desenvolvimento Científico e Tecnológico do Estado do Paraná and to the Conselho Nacional de Desenvolvimento Científico e Tecnológico (CNPq) for financial support.

\section{REFERENCES}

Al-Omari, A. \& Fayyad, M. 2003. Treatment of domestic wastewater by subsurface flow constructed wetlands in Jordan. Desalination. 155(1): 27-39

American Public Health Association (APHA). 1998. Standard Methods for the Examination of Water and Wastewater (20th ed). Washington, DC.

Anjos, J.A.S.A. 2003. Avaliação da eficiência de uma zona alagadiça (wetland) no controle da poluição por metais pesados: o caso da Plumbum em Santo Amaro da Purificação/BA. Tese de Doutorado em Engenharia: Engenharia Mineral. Escola Politécnica da Universidade de São Paulo. 328p.

Bertholdo, D.T. 1999. Eficiência de banhados construídos no tratamento de águas provenientes da drenagem urbana e no pós-tratamento de efluentes líquidos tratados por processo anaeróbio (Reator UASB) e no tratamento de drenagem urbana. Dissertação de Mestrado. Universidade Federal do Rio Grande do Sul - UFRGS. 115p.

Chapra, S. C. Surface Water Quality Modeling. New York: McGraw-Hill Companies, Inc, 1997.

Conselho Nacional do Meio Ambiente (CONAMA). 2011. Resolução $n^{\circ} 430$, de 13 de maio de
2011. Dispõe sobre as condições e padrões de lançamento de efluentes, complementa e altera a Resolução n 357, de 17 de março de 2005, do Conselho Nacional do Meio Ambiente-CONAMA., 89p.

Daigo, M.J. 1997. Metal removal in a pilot scale upflow macrophyte system. Master Thesis, Chalmers University of Technology, Department of Sanitary Engineering. 68p.

Dunbabin, J.S. \& Bowmer, K.H. 1992. Potential use of constructed wetlands for treatment of industrial wastewaters containing metals. Sci. Total Environ. 111(2-3): 151-168

Faquin, V. 2005. Nutrição Mineral de Plantas. Monografia de Especialização em solos e meio ambiente. Universidade Federal de Lavras - UFLA. $186 \mathrm{p}$.

Fia, F.R.L. 2009. Modelos de remoção de matéria orgânica e nutrientes de águas residuárias da suinocultura em sistemas alagados construídos. Doutorado em Engenharia Agrícola. Universidade Federal de Viçosa. 160p.

Galletti, A.; Verlicchi, P \& Ranieri, E. 2010. Removal and accumulation of $\mathrm{Cu}, \mathrm{Ni}$ and $\mathrm{Zn}$ in horizontal subsurface flow constructed wetlands: Contribution of vegetation and filling medium. Sci. Total Environ. 408(21): 5097-5105

García, I.R. 2003. Constructed wetlands use for cyanide and metal removal from gold mill effluents. 20p. Available at <. http://www2.Iwr.kth.se/ Publikationer/PDF_Files/LWR_EX_03_2.PDF>. Accessed on September 3, 2013.

Hill, D.T. \& Payton, J.D. 2000. Effect of plant fill ratio on water temperature in constructed wetlands. Bioresource Technol. 71(3): 283-289.

Instituto Agronômico do Paraná (IAPAR). Cartas Climáticas do Paraná - classificação climática. Available at < http://www.iapar.br/modules/ conteudo/conteudo.php? conteudo $=863>$. Accessed July 10, 2013. 
International Water Association (IWA). 2000. Constructed Wetlands for Pollution Control: Processes, Performance, Design and Operation. Scientific and Technical Report $n^{\circ}$. 8. London, England: IWA Publishing, 156p.

Jordão, C.P.; Alves, N.M.; Pereira, J.L.; Bellato, C.R. \& Alvarez, V.H. 2000. Adsorção de íons Cu2+ em latossolo vermelho-amarelo húmico. Quím. Nova. 23(1): 5-11.

Maine, M.A.; Suñe, N.; Hadad, H.; Sánchez, G. \& Bonetto, C. 2007. Removal efficiency of a constructed wetland for wastewater treatment according to vegetation dominance. Chemosphere. 68(6): 1105-1113.

Marques, D.M.L.M.; Pinheiro, C.B. \& Luca, S.J. 1997. Controle de metais e elevação de $\mathrm{pH}$ por banhado (wetland) construído sem fonte externa de matéria orgânica. Anais: XIX Congresso Brasileiro de Engenharia Sanitária e Ambiental - ABES.

Mota, F.S.B. \& Von Sperling, M. (Coordenadores) 2009. Nutrientes de esgoto sanitário: utilização e remoção. $1^{\text {a }}$ Edição. Projeto PROSAB. Rio de Janeiro: ABES. ISBN: 978-85-7022-164-3. 428p.

Neralla, S.; Weaver, R.W.; Lesikar, B.J. \& Persyn, R. A. 2000. Improvement of domestic wastewater quality by subsurface flow constructed wetlands. Bioresource Technol. 75(1): 19-25.

Ran, N.; Agami, M. \& Oron, G. 2004. A pilot study of constructed wetlands using duckweed (Lemna gibba L.) for treatment of domestic primary effluent in Israel. Water Res. 38(9): 2241-2248.

Santiago, A.F.; Calijuri, M.L. \& Luís, P.G. 2005. Potencial para a utilização de sistemas de wetlands no tratamento de águas residuárias: uma contribuíção a sustentabilidade dos recursos hídricos no Brasil. Nat. \& Desenv. 1(1): 29-39.

Schirmer, W.N \& Oliveira, G.L. 2010. Desodorização de efluentes líquidos tratados em leito de zona de raízes ("wetlands"). $R$. Tecno-lógica, 14(1): 11-19.

Schirmer, W.N.; Machado, G.O.; Stumpf, G.; Lemes, J.L.V.B.; Agassi, J.D. \& Van Kaick, T. 2009. Tratamento de esgoto por zona de raízes em comunidade rural - Parte 2: avaliação. Rev. Acad. Ciênc. Agrár. Ambient. 7(2): 165-173.

Schirmer, W.N.; Ottaviano, L.M.; Gomes, S. \& Vieira, M.M. 2012. Evaluation of treated sewage deodorization in root-zone wetlands through dynamic olfactometry. J. Urban Environ. Eng. 6(2): 113-122.

Scholes, L.; Shutes, R.B.E.; Revitt, D.M.; Forshaw, M. \& Purchase, D. 1998. The treatment of metals in urban runoff by constructed wetlands. Sci. Total Environ. 214(1-3): $211-219$.
Shutes, R.B.E. 2001. Artificial wetlands and water quality improvement. Environ. Int. 26(5-6): 441-447.

Solano, M.L.; Soriano, P. \& Ciria, M.P. 2004. Constructed wetlands as a sustainable solution for wastewater treatment in small villages. Biosystems Engineering. 87(1): 109-118.

Sousa, J.T.; Haandel, A.V.; Lima, E.P.C. \& Henrique, I.N. 2004. Utilização de wetland construído no póstratamento de esgotos domésticos pré-tratados em reator UASB. Eng. Sanit. Ambient. 9(4): 285-290.

Stottmeister, U.; Wießner, A.; Kuschk, P.; Kappelmeyer, U.; Kästner, M.; Bederski, O.; Müller, R. A. \& Moormann, H. 2003. Effects of plants and microorganisms in constructed wetlands for wastewater treatment. Biotechnol. Adv. 22(1-2): 93-117.

United States Environmental Protection Agency (USEPA). 2000. Constructed wetlands treatment of municipal wastewater. EPA/625/R-99/010. Ohio: Cincinati, National Risk management Research Laboratory, Office of research and Development.

Valentim, M.A.A. 2003. Desempenho de leitos cultivados ("constructed wetland") para tratamento de esgoto: contribuições para concepção e operação. Tese de Doutorado. Universidade Estadual de Campinas - UNICAMP. 210p.

Van Kaick, T.S. 2002. Estação de tratamento de esgoto por meio de zona de raízes: uma proposta de tecnologia apropriada para saneamento básico no litoral do Paraná. Dissertação de Mestrado Programa de Pós-Graduação do PPGTEE. Centro Federal de Educação Tecnológica do Paraná. $128 p$.

Verhoeven, J.T.A. \& Meuleman, A.F.M. 1999. Wetlands for wastewater treatment: Opportunities and limitations. Ecol. Eng. 12(1-2): 5-12.

Water Environment Federation (WEF). 1995. Odor Control in Wastewater treatment Plants: Manual of practice n. 2. New York: ASCE Manuals and Reports on Engineering Practice n. 82, 282p.

Weis, J.S. \& Weis, P. 2004. Metal uptake, transport and release by wetland plants: implications for phytoremediation and restoration. Environ Int. 30(5): $685-700$. 